\title{
AKTUALNI OSVRT
}

\section{Rizici od protesta izdanih državnih jamstava}

dr. sc. ANTO BAJO

\begin{abstract}
U prilogu polugodišnjeg izvještaja o izvršenju Državnog proračuna za 20Ir. koji je Vlada poslala Saboru na raspravu i usvajanje nalazi se i Izvješće o izdanim jamstvima ${ }^{\top}$. To Izvješće ukazuje da je Hrvatska i dalje izložena rizicima protesta jamstava koja bi se lako mogla pretvoriti u dug opće države. Posebice zabrinjava što su aktivna jamstva od o,7\% BDP u 1996. porasla na čak I6,6\% BDP-a u 2011.
\end{abstract}

\section{Državna jamstva - izravni ili potencijalni dug Hrvatske}

Jamstva uglavnom odobrava Vlada, a dio i Sabor za zajmove od međunarodnih financijskih institucija (EBRD, Svjetska banka, itd.). Od 1996. do lipnja 20II. Vlada i Sabor odobrili su ukupno I.257 državnih jamstava u iznosu od I48,2 mlrd. kuna. Od toga je bilo I.O22 financijskih u iznosu od II3,2 mlrd. kuna i 235 činidbenih u iznosu od $35 \mathrm{mlrd}$. kuna. Od 1996. do 20II. prosječno je 74\% odobrenih financijskih jamstva u eurima, I5\% u kunama i iı\% u US dolarima. Oko 53\% jamstava dano je na zaduživanje u inozemstvu (kod poslovnih banaka i međunarodnih financijskih institucija) i $47 \%$ na zaduživanje u Hrvatskoj.

Aktivna jamstva rastu s 0,7\% u 1996. na I6,6\% BDP-a u 20II. Aktivna jamstva su do 2008. u prosjeku činila oko 8\% BDP-a. Od 2008. do lipnja 20II. njihov je udio porastao dvostruko, odnosno za 8,6 postotna boda.

Vlada u 20II., nakon stanke od četiri godine, ponovno odobrava činidbena jamstava brodogradilištima ${ }^{2}$, međutim, u Izvješću o izdanim jamstvima za prvo polugodište 20II. nema informacija o toj vrsti jamstva iako je izdano početkom lipnja $201 I$.

Postoji velika vjerojatnost da Vlada u 20II. probije limit od 4,9 mlrd. kuna za izdavanje financijskih jamstava. Samo u prvoj polovici 20II. odobreno je 3,8 mlrd. kuna što je oko 80\% ukupnog limita za 20II. Uz višegodišnju Vladinu praksu ne pridržavanja postojećih ograničenja teško je vjerovati da bi imalo smisla uvesti dodatna zakonska ili ustavna fiskalna ograničenja (pravila) na jamstva i javni dug.

Jamstvena pričuva za cijelu 20II. iznosi I mlrd. kuna, a Vlada je već u prvom polugodištu iz te pričuve potrošila 667 mil. kuna zbog protesta jamstava. Protestirana su jamstva dana brodogradilištima (Brodosplit, Brodotrogir, Uljanik, Kraljevica, 3. maj), hotelskim društvima (Plat, Šolta, Medena, Vis, Živogošće, Podgora, Hum, Omišalj i Lipik), poljoprivrednom poduzeću (IPK Osijek), Vjesniku, Croatia Airlinesu te dvjema lokalnim jedinicama (Vukovar i Imotski). Njihove dospjele kreditne obveze u

${ }^{\mathrm{I}}$ http://www.sabor.hr/Default.aspx?art=40889

${ }^{2}$ http://www.vlada.hr/hr/naslovnica/sjednice_i_odluke_vlade_rh/20II/I46_sjednica_vlade_republike_hrvatske 
iznosu od 646 mil. kuna Vlada je podmirila iz jamstvene pričuve, a 2I mil. kuna primicima od regresne naplate jamstava od dužnika. Zanimljivo, u prvoj polovici 20II. državna Hrvatska poštanska banka je protestirala 54 mil. kuna jamstava. Od 2006. do lipnja 20II. brodogradilišta i HŽ zadužili su se, uz državno jamstvo, kod HPB-u iznosu od I,3 mlrd. kuna. Napomenimo da je Vlada u 20Io. s 450 mil. kuna iz državnog proračuna ponovno dokapitalizirala HPB.

Od 1998. do 20II. Vladi je došlo na naplatu (protestirano) 9,8 mlrd. kuna jamstava, a samo u posljednje dvije i pol godine oko 2,9 mlrd kuna. Izvorni dužnici su od 1998. do 20II. vratili državi samo 606 mil. kuna ili $6,7 \%$ od ukupno protestiranog iznosa jamstava.

Vlada je relativno dobro procijenila mogućnosti protesta jamstava zbog čega od 2008. u jamstvenu pričuvu ostavlja godišnje po I mlrd. kuna. Nažalost, sredstva jamstvene pričuve u 2009. čak nisu bila dovoljna zbog protesta 2 mlrd. kuna zbog čega je Vlada morala koristiti dio sredstava iz proračuna i dio primitaka od zaduživanja izdanjima obveznica.

U travnju 20II. dug brodogradilišta od II,3 mlrd. kuna pretvoren je u dug opće države ${ }^{3}$. Jednim administrativnim potezom Vlada je povećala dug opće države i smanjila potrebu izdavanja novih jamstava u drugoj polovici predizborne 20II. Dug brodogradilišta dospijevat će do 20I4., a nakon toga prisutni su potencijalni rizici dospijeća jamstava izdanih Hrvatskim autocestama i Hrvatskim cestama. Međutim, po tim jamstvima manji su rizici protesta jer ova trgovačka društva osiguranje mogu jamčiti naplatom naknada. Istina, naplaćeni prihodi od naknada su u kunama, a većina kreditnih obveza društava je $u$ eurima što ukazuje na potrebu da Vlada vodi računa o valutnoj strukturi obveza svih društava kojima odobrava jamstva radi izbjegavanja rizika moguće promjene tečaja kune i dodatnog povećanja obveza.

Društva kojima država odobrava jamstva stvorila su kreditne obveze do 2037. godine. Iako je prosječna ročnost izdanih jamstava u 20II. oko pet godina, većina izdanih jamstava potencijalno bi mogla dospjeti na naplatu za dvije do tri godine što dodatno stvara pritiske i potrebu za njihovo refinanciranje. Od 2007. do 20II. skraćuje se vrijeme dospijeća izdanih jamstava na oko četiri godine te se vraća u razdoblje od I996-99. kada su vjerovnici odobravali kredite društvima korisnicima jamstava s kraćim rokovima dospijeća. Time su vjerovnici za odobrene kredite uz državna jamstva penalizirali ne samo slabu kreditnu sposobnost izvornih dužnika nego i države. Vlada treba utvrditi ukupnu visinu i strukturu obveze izvornih dužnika te nastojati produljiti ročnost kredita uz koja se izdaju jamstva. Na taj bi se način spriječilo gomilanje obveza u kratkom roku (dvije do tri godine) kada usporedno s jamstvima dospijeva i značajan dio glavnice i kamata izdanih državnih obveznica. Dospjele obveze za kamate i glavnicu izdanih obveznica rastu s II,I mlrd. u 20I2., na I5,6 mlrd. u 20I3., te na čak I6,6 mlrd. kuna u 2014.

${ }^{3}$ Zakon o uređenju prava i obveza brodogradilišta u postupku restrukturiranja, NN 6I/II. 